The $5^{\text {th }}$ International Conference on Family Business and Entrepreneurship

\title{
LOCKDOWN POLICY AND ITS IMPACT ON EMPLOYEE TERMINATION AND RESTAURANT SUSTAINABILITY IN INDONESIA AND EUROPEAN COUNTRIES
}

\author{
Nurianna Thoha ${ }^{1 *}$, Burhanudin ${ }^{2}$, Marko S Hermawan ${ }^{3}$, Levi Fernanda Aditya ${ }^{4}$ \\ ${ }^{1,2,3,4}$ Computer Science Department, School of Computer Science, Bina Nusantara University, \\ Corresponding author: nurianna@binus.edu
}

\begin{abstract}
This research investigates employee termination decisions and the impact on restaurants' sustainability during the COVID-19 pandemic. Restaurants in Indonesia, Germany, and the Netherlands have been affected by the lockdown policy that led to job cuts and termination of restaurants' employees in those three counties. Therefore, the restaurant owners must cope with the lockdown situation in their country and find the best strategy to survive. This research is qualitative research that was conducted by using in depth semi-structured interviews to collect data from twelve interviewees who are working in three restaurants in Indonesia, and one restaurant each in Germany and the Netherlands. Due to the distance and the pandemic, most of the interviews were conducted online. All restaurants in this research are included in the casual restaurant category. This research found several factors of the termination process of the restaurant employees were included in the employee performance and employee enforcement factors. This research also discovered a relationship between the dismissal process and the sustainability of the restaurants during the COVID-19 pandemic that varied greatly among the three countries: Indonesia, Germany, and the Netherlands. The factors that influenced the restaurants' sustainability included restaurant profit, government regulations, and the ways the restaurants' owners or management navigated the pandemic effects. The results of this study will be useful to provide insight for businesses in the field of food and beverages, especially for restaurants during the COVID-19 pandemic.
\end{abstract}

Keywords: Employee Termination, Lockdown, Restaurant Sustainability

\section{Introduction}

It was in late 2019 when a new virus called SARS-CoV-2 was identified and found deadly to humanity by attacking the respiratory system and infecting other organs in the human body. The SARS Novel Coronavirus' new variant first appeared in Wuhan city, Hubei Province, China. As of March 7, 2021, there have been 38,756,104 confirmed cases of coronavirus (COVID-19) across Europe since the first confirmed cases in France on January 25, 2020, (Stewart, 2021). The virus spread rapidly around the globe causing emergency services all over the world to be overloaded. Therefore, the World Health Organization (WHO) made an assessment that the Coronavirus SARS-CoV-2 or COVID-19 (Coronavirus Disease, 2019) could be characterized as a pandemic (WHO, 2020).

After the declaration of the COVID-19 pandemic by WHO, many countries responded by issuing their own regulations to control and prevent the spread of the virus that included health campaigns, education, volunteering and even total lockdowns in some areas that were flagged as 'red zones' or had a higher number of infections. Lockdowns had the biggest impact to prevent the spread of the virus. It refers to measures being placed on the whole society to restrict movement and use of services to the essentials, of 
which mass quarantining is a part (Future Learn, 2021). In other words, lockdown means an emergencylike system under which private and public offices, private establishments, and public transport are completely closed (Joseph, 2021).

The lockdown regulations forced countries to adapt to new changes, especially in the business sector. Since March 2020, the COVID-19 pandemic has caused massive disruption and pushed companies to cut workers. According to Ridwan Kamil, governor of West Java, Indonesia, over 2000 companies were impacted by the pandemic. Middle to small level businesses were cutting their employees as a response to low profits and cut the wages for their employees. West Java Manpower and Transmigration Agency head, Rachmat Taufik Gardasil, said that as of October, around 460 companies had officially cut the number of workers that caused 19,089 employees had been laid off. (The Jakarta Post, 2020).

\section{Unemployment Rate in Indonesia, Germany, and the Netherlands}

The COVID-19 pandemic has had a significant impact all over the world in every aspect, including the unemployment rate in Indonesia. Indonesia experienced an increase in the unemployment rate from $4.3 \%$ in 2016 to $6.3 \%, 7.4 \%$, and $7.2 \%$ in 2017 to 2019 respectively (Indonesia Investment, 2021). The highest increase to $9.1 \%$ occurred in 2020 when the COVID-19 pandemic occurred at the beginning of the year. According to Indonesia's Ministry of Manpower, 3,066,567 workers were affected by the COVID-19 situation, so they had to be laid off or sent home in March 2020 (Roy, 2020).

Due to COVID-19, the government of Indonesia imposed a lockdown regulation closure period from March 24 to the end of July 2020. Then the Indonesian government enacted 'Large Scale Social Distancing' $(P S B B)$ regulations in almost all the regions of Indonesia to reduce transmission and to slow down the spread of COVID-19. These included the closure of the restaurant sector which increased the unemployment rate. That closure meant food and beverages $(F \& B)$ services experienced a sudden drop in growth from 6.92\% in Q4 2019 to 3.52\% in Q1 2020. GDP growth of the restaurants also dropped from $5.02 \%$ in Q4 2019 to $2.97 \%$ in Q1 2020 (Indonesia Investment, 2021).

COVID-19 pandemic also affected European countries, including Germany and the Netherlands. The average unemployment rate in Germany continued to decline from $6.1 \%$ in 2016 to $5 \%$ in 2019, but an increase of $0.9 \%$ to $5.9 \%$ occurred in 2020, when the pandemic hit (Statista, 2020). Unemployment rates increases also happened each month in 2020, from 3.4\% in January to $4.6 \%$ in November (Federal Statistics Germany, 2020). Germany instituted a policy not to carry out mass layoffs to suppress the unemployment rate by implementing the 'Kurz Arbeit' policy. Kurz Arbeit is a social insurance program whereby employers reduce their employees' working hours instead of laying them off, which provides an income 'replacement rate' of $60 \%$ Invalid source specified..

The COVID-19 pandemic caused Germany's restaurant industry to experience a huge impact. Due to measures of social distancing and general caution in public places, consumers were forced to dine out less. This caused a year-over-year change of seated diners in restaurants in Germany with only $35 \%$ on September 2, 2021, compared to the equivalent number in 2019 Invalid source specified..

In the Netherlands, the COVID-19 pandemic impacted the Dutch capital the hardest, as the unemployment rate in Amsterdam and the surrounding area was far more pronounced than the rest of the country. The number of people looking for work in Amsterdam grew faster than the rest of the country.

The unemployment rate in the Netherlands was declining since 2016 from $6.1 \%$ to $2.9 \%$ in 2020 (Statista, 2020). However, looking at the detail of the unemployment rate per month in 2020, when the COVID-19 pandemic hit, the trend showed an increase in March from 2.9\% to 4.3\% in November with a peak of $4.6 \%$ in September (Statista, 2020). Those increases made 15,000 people unemployed with a total of 419,000 people in the Netherlands out of work (Seveno, 2020).

\section{Problem Discussion}

Based on the above data, the problem in this study is the high number of restaurant employees in Indonesia, Germany, and the Netherlands that were affected by the COVID-19 pandemic and the differing situations in lockdown regulations that made a serious impact on restaurants, slowing business and potentially affecting the restaurants' sustainability. Indonesia, Germany, and the Netherlands were chosen because Indonesia has been quite slow in overcoming the COVID-19 pandemic in Southeast Asia (Muhammad, 2020). On the other hand, Germany, and the Netherlands were among the fastest and foremost countries in dealing with this pandemic (Belluz, 2020). Therefore, the research questions for this study are: What are the basis and process of employee termination decisions to support the restaurants' sustainability in Indonesia, Germany, and the Netherlands? How do restaurants in Indonesia, Germany, and the 
Netherlands sustain themselves during the pandemic? Meanwhile, the objectives of this research are to discover the basis and process to lay off employees in the restaurant industry due to the COVID-19 pandemic in Indonesia, Germany, and The Netherlands, and to discover the restaurants' strategy to sustain themselves after laying off their employees.

\section{Literature Review}

The F\&B industry business includes restaurants, cafes, canteens, fast foods, bars, catering, and others. The businesses are focusing on serving customers with food and drinks to satisfy the customers' dining experience. Both dine-in and online services are available in this industry (Insight Talenta, 2020). F\&B businesses mostly are in the form of SMEs (small and medium enterprises) with revenues, assets, or numbers of employees that fall below a certain level; the criterion for determining an SME varies between countries and sometimes between industries (Ward, 2020). Restaurants as the front line of the F\&B services, faced many challenges due to the pandemic, as governments around the world decided to implement lockdowns and social distancing (Jain, 2020). This led to a rapid shutdown of restaurants and hotels.

\section{Lockdown Schemes in Indonesia, Germany, and the Netherlands}

Since Indonesia was affected by the COVID-19 pandemic in early March 2020, the government immediately implemented a lockdown system. Jakarta, the capital city, was the first area to implement a lockdown. Since then, several regions in Indonesia have implemented lockdown systems to reduce people's mobility and curtail the spread of the Coronavirus. Lockdown policies/terms used in Indonesia include: 1. PSBB (Large-Scale Social Restrictions) that were implemented on April 10th, 2020, in Jakarta, soon followed by other provinces. 2. PPKM (Enforcement of Restrictions on Community Activities) - was implemented to keep the number of COVID-19 cases low. PPKM also regulated the opening business hours and limited the capacity in public places such as restaurants, malls, and offices.

In Germany, the lockdown scheme or curfew was also implemented since the COVID-19 pandemic hit on March 22, 2020. A curfew is a strict order that is issued by the administration to keep people off the streets (Joseph, 2021). In general, the use of the term curfew is used and applied in an area to prohibit people from leaving their homes or roaming freely on the streets (Plumer \& Neumayer, 2020), that include restrict personal contact to one household and one other person; implement a time restriction; ensure non-essential shops only allow customers in with a negative COVID-19 test who have made an appointment; close inschool teaching; and limit funerals to 30 mourners.

In the Netherlands, an 'intelligent lockdown' was first carried out in March 2020 to respond to and slow down the spread of the virus, to reduce the social, economic, and psychological costs of social isolation, as well as to make the return to normalcy more bearable (Holigan, 2020). As a result, several sectors have been paralyzed, such as restaurants, bars, and cafes because they must close down for a certain period. People have been instructed to stay at home, but if the citizens cannot work from home or needs groceries or fresh air, they can go out by keeping a $1.5 \mathrm{~m}$ (5ft) social distance. Some of the regulations during the lockdown in the Netherlands in 2020 included: the closing of the hospitality industry; the closing of bars and restaurants; limiting group sizes; the closing of sports events; the closing of public events; and face masks must be worn in indoor spaces.

\section{Business Slowdown}

At the beginning of the COVID-19 pandemic, almost all business sectors were paralyzed, from large enterprises to SMEs. In the F\&B sector, business actors were greatly affected by the COVID-19 pandemic. People were very afraid of the Coronavirus; therefore, people were reluctant to buy food and drinks because they were afraid that the virus had spread and contaminated the food and drinks being sold. Survey results show around $47 \%$ of the respondents said that they were eating more home-cooked meals and ordering less takeout or delivery than usual, while $16 \%$ of the respondents said that they were ordering more often than they used to (Food Insight, 2020).

\section{Employee Termination in Indonesia, Germany, and the Netherlands}

Employee termination is the release of an employee against his or her will, at will, for cause, or for lack of work (Inc, 2020). As a company has the right to lay off its employees in some situations - like the COVID19 pandemic before the government regulated work from home - most companies chose to lay off employees (Prawithra \& Sri, 2020). Terminating an employee must follow the standard procedure and have a valid business reason for the action. The process of employee termination varies from one country to another, for example the employee termination process in Indonesia, Germany, and the Netherlands differ. 
In Indonesia, employee termination as stated in the Manpower Act No. 13 of 2003 CHAPTER I Article 1 paragraph (25), "Termination of employment is the termination of a working relationship due to certain reasons which result in the termination of rights and obligations between the worker/laborer and the entrepreneur" (Insight Talenta, 2020).

In Germany dismissals must be declared clearly and explicitly due to their significant implications. Termination of an employment agreement must be in the form of an agreement or written statement that according to applicable regulations cannot be waived by a work agreement or collective labor agreement. The Termination Protection Act became the basis for the dismissal of employees in Germany. Three reasons are covered in the Termination Protection Act: personal, behavior, and the business situation (Meier, 2019). In the Netherlands, dismissing employees requires a valid reason. Refusal to do work, culpable behavior, excessive sick leave, reorganization, or corporate closure are all valid grounds (Netherlands Enterprise Agency, 2021). If an employee accepts to be laid off, there are two options: first, a mutually agreed-upon dismissal; secondly, termination with the approval of the other party. This means the business decides to terminate its employee's employment contract and the employee signs a written agreement to do so.

\section{Business Sustainability Strategy}

During the COVID-19 pandemic, many businesses are looking for ways to maintain their businesses and make profit. In F\&B businesses, owners are pinning their hopes on digitization to keep selling their goods to customers and make a profit. Nowadays, people do not come and order dine-in meals but simply tap their phone and order the food from the selected restaurant. In urban areas, this method works well because the internet services are sufficient. Since one-third of the world's population was on lockdown in early 2020, global food security alerts have arisen and impacted F\&B businesses (Business Insider, 2020). The lockdowns that were enforced in many countries caused F\&B businesses to find ways to continue selling their products by using alternative ways to stay connected with their customers by doing business ranging from delivery services, takeaway only, employee shift, virtual markets, $25 \%$ dine in capacity, and others.

\section{Hough Theory of Unemployment}

The automatic theory of employee termination by Hough is used as a framework to analyze the findings of this research. The theory has the presumption against specific performance of a contract employment (Hough, 2003). According to Hough, unemployment can be conducted if at the policy level of a contract, an employee can be found to have made an error that is far from good performance. However, the automatic theory also requires enforcement of employees which relies upon the idea that the performance of work is the consideration for wages (Hough, 2003). Employee performance and employee enforcement affect the decision to lay off employees in a company. Employees play an important role as the main actors in achieving the goals of a company. Therefore, a company must pay attention to certain aspects so that employee performance remains prime (Hough, 2003). On the other hand, employee enforcement is a set of rules to regulate employees. These rules cover everything for every employee, from admission to dismissal. Based on the above discussion, Figure 1 shows the conceptual framework for this research.

\section{Research Method}

This research was conducted by using qualitative research method, and the philosophy of this research is interpretivism. Figure 2 shows the design of this research. The research approach is deductive reasoning; that is, developing conclusion from a generalization of a known fact and using a theory-driven focus to identify codes and themes that relate to the existing theory (Braun \& Clarke, 2006; Kiger \& Varpio, 2020). Purposive sampling was applied for this research and the unit analysis was three restaurants with six interviewees in Indonesia (in Tangerang, Bali, and Jakarta), one restaurant with three interviewees in Germany (Berlin), and one restaurant with three interviewees in the Netherlands (Amsterdam), that have laid off and had self-unemployment among its employees due to the COVID-19 pandemic. 


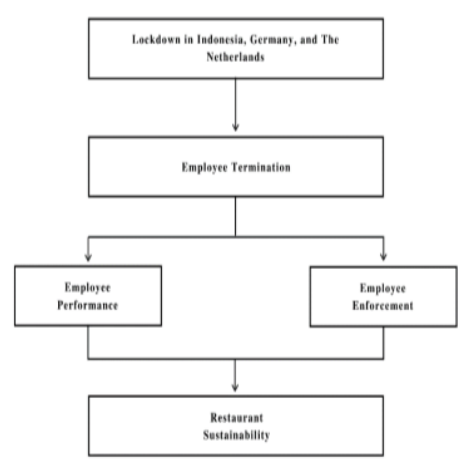

Figure 1. Conceptual Framework. (Source: Adjusted by the researchers, 2021)

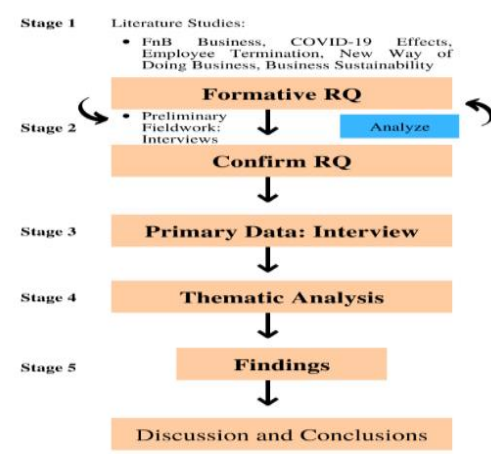

Figure 2. Research Framework (Source: Modified from Thoha \& Avandana, 2021)

The interviewees were the owner/co-owner, managers, employees, and ex-employees of those restaurants. At least two people were interviewed from each restaurant for triangulation purposes and to confirm the validity of the research data. The twelve interviews were conducted using in-depth semi-structured interviews through Zoom interviews and WhatsApp calls. The interviews were recorded, and the data was used to develop the transcripts, which were then analyzed using thematic analysis to identify the common themes, topics, ideas, and patterns of meaning that came up repeatedly. By using these transcripts, the researchers employed an-inductive (bottom-up) approach, where the researchers begin with specificobservations through the process of various coding processes to come up with a description in regard to the phenomenon or issue being discussed (Creswell, 2009). The data were manually coded by first creating themes or categories of information (open coding) from the interview transcripts, relating or linking the categories from one another (axial coding), and analyzing the relations from the interconnections between categories (selective coding); doing so allowed the researcher to generate an essence description (Creswell, 2009) pertaining to the research topic.

\section{Results and Discussion}

\section{Employee Termination Process in Indonesia}

Employee dismissals occurred in Indonesia during the COVID-19 pandemic, especially in the restaurant sector. As can be seen in Figure 3, the nodes (descriptions) that were found in the interviews' transcripts formed categories of Employee Performance and Employee Enforcement, which confirmed Hough's theory regarding termination of the contract employment (Hough, 2003). NV, a restaurant owner in South Tangerang, Banten, Indonesia said "The first one is the evaluation of their performance; we always do an evaluation per three month". So, one of the factors of his dismissal decision is based on the employee evaluation report. Furthermore, there is also an application of employee dismissal based on Employee Enforcement or agreements between the restaurant management and the employee that is in line with Hough's theory (Hough, 2003). For example, AR, a restaurant owner in Bali said, "At first, we did dismissal of employees by giving them one month right? I negotiated the salary, paying $50 \%$ of their salary, but then the restaurant could not be opened yet, the condition was even worse, so unfortunately eventually I terminated them". AR knew from the beginning that the pandemic would have an impact on the dismissal of employees so that to minimize dismissal, he negotiated with his employees to cut their salary by $50 \%$, but the situation of the COVID-19 pandemic got severe, so he was forced to lay off all his employees. The interviewees' statements above formed the nodes (descriptions) of employee monthly reports, unclear situations, work shifts, forced termination, business closures, and salary cuts (Figure 3).

$\mathrm{RO}$, an ex-employee at a restaurant in South Tangerang, Banten said "I didn't get a call to come back to work, instead they called me saying that we are in the middle of a pandemic and there is employee restriction so casual workers may not be called to come back to work until the time specified. It's like being terminated softly". Based on that statement it can be concluded that the restaurant owners laid off the employees by giving direct notifications. 


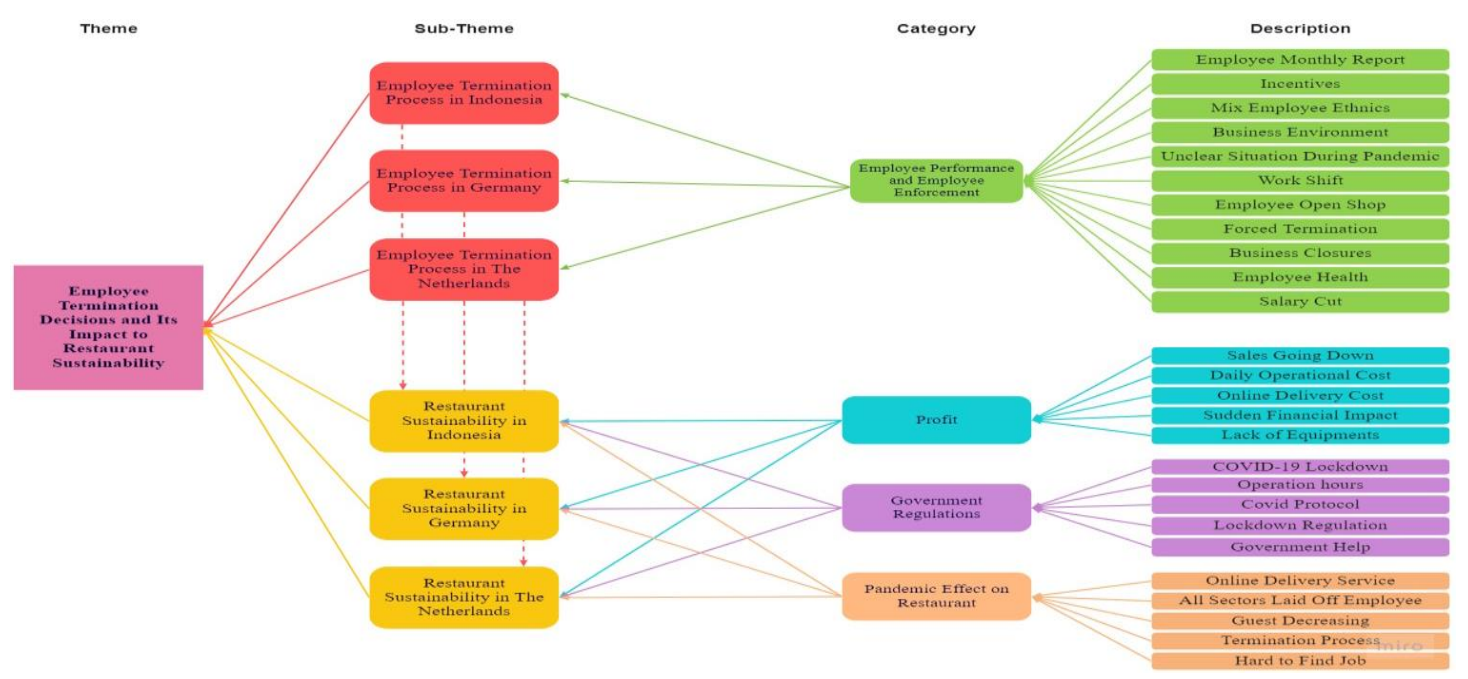

Figure 3. Coding Mapping

(Source: Interview data, processed with manual coding, 2021)

\section{Employee Termination Process in Germany}

The dismissal process in Germany according to $\mathrm{KH}$, the field manager of the $\mathrm{AC}$ restaurant, is: "if anyone wants to resign, they can immediately speak for the appropriate reasons". So according to him, the process of dismissing employees that occurred at AC restaurant in Germany was by using direct communication from the employees who submitted their resignations to the restaurant manager.

The Employee Termination Process in Germany sub-theme was developed from the Employee Enforcement category. Furthermore, KH said, "There were several employees who resigned due to being overworked". One of his employees resigned because of the double shifts and overwork due to the lack of employees at the restaurant. In addition, GI, an ex-employee of the AC restaurant said, "I found a job in Berlin, so that's not a big problem, the job in Berlin pays more". GI decided to quit because he said the income from working in a restaurant was very low, so he switched to another profession that paid more.

\section{Employee Termination Process in the Netherlands}

ER, the BP restaurant owner in the Netherlands, said "You must go to the government and discuss it; you cannot just fire the employee. You must pay a little bit, because if they get fired, they must go to the government system and get some money if they are unemployed". Meanwhile, ST the field manager of BP restaurant, said "We didn't really have a procedure actually, so you said you would quit that day and we're just say okay, fine, and we paid them, so it's really informal because we are a small business". It can be concluded that the process of termination of employee in BP restaurant was done only by verbal communication; they did not have a process that is in accordance with local regulations because they considered that their restaurant was just a small business. This statement was also supported by the previous statement from ER at BP restaurant that said about the complex process of termination with government intervention. ST also said that one of the employees resigned because she got another job with a better pay, while the other resigned because he would like to pursue his study to a master's program, so it was difficult to match the schedule of school and work in the restaurant. He also added that several employees resigned because of overwork and the low salary.

\section{Restaurant Sustainability in Indonesia}

Restaurants in Indonesia were really hit by the pandemic and lockdown; they were forced either to terminate their employees and close the business or their employees resigned. The Restaurant Sustainability in Indonesia sub-theme was developed based on three categories: profit, government regulation, and effect of COVID-19 pandemic on restaurants.

Profit is one of the indicators for a sustained or un-sustained restaurant. The profit category was formed from the descriptions of sales going down, daily operational costs, online delivery costs, sudden financial impact, and lack of equipment. NV, the owner of SR restaurant said that the restaurant's revenue was very 
dependent on events like seminars and wedding receptions that were usually held in his restaurants. During the pandemic there were no such events conducted that caused the restaurant's revenue to decline drastically affecting the restaurant's profits. A similar statement was made by NVI, the owner of BAS restaurant in Jakarta: "Before the pandemic the restaurant's monthly revenue was 150 million. But when the PSBB was implemented, our income turned to about a million, a million and a half. It decreased a lot".

Government regulations on COVID-19 pandemic also affected the sustainability of restaurants, they were quite burdensome for the F\&B sector. NV from SR restaurant says: "The first PSBB people were very prohibited to dine in, the operational hours were also restricted... It really affected us." Meanwhile, government regulations also regulated the operating hours and dining provisions in place. RI from SR restaurant said: "Restaurants can open until $8 \mathrm{pm}$, then we must close,... dine in was possible but with a maximum of two people". On the other hand, the government also provides financial assistance: "Right. BPJS employment, from the government for the employee," said RI, an ex-employee from SR restaurant. Government assistance funds were also given for the restaurant management, but several of them did not receive it because of poor communication between the government and the business owner as AR, the restaurant owner in Bali, said, "It used to be there, but because I did not monitor it, I did not receive it". The pandemic effect on the restaurant category was developed based on several descriptions of interview findings, namely all sectors laid off employees, visitor rates decreased, the termination process, hard to find jobs, and online delivery services. AR, the restaurant owner in Bali said, "Well, compared to previous years, during the lunar time in 2020, the Chinese tourists were approximately reduced by 50\%". The decline of the number of tourists occurring at the beginning of the pandemic resulted in a lack of buyers at this restaurant. Another example was given by NV, the owner of SR restaurant who said "We had 30 employees before COVID... but because of COVID we had to decrease the number of our employees because our profits were not as usual. Even though it was very hard we must terminate several of them".

Meanwhile in terms of service, online delivery service was very helpful for increasing the sales where at the time of lockdown the restaurant should not accept on-site diners. NV from SR restaurant said "Since we already operated for a long time and we also have our own market, and even before COVID we already have our online services like GoFood and Grab, we also have our own delivery service. So even though our profits are decreasing we still get some sales from the online sales".

\section{Restaurant Sustainability in Germany}

The Restaurant Sustainability in Germany sub-theme was developed based on three categories: profit, government regulation, and the effect of the COVID-19 pandemic on restaurants. Respondents in Germany managed to keep their restaurants open during the pandemic and lockdown. For the profit earned during the lockdown and during the pandemic, $\mathrm{KH}$, the field manager of AC restaurant in Berlin, said "At first there was a drastic decrease in our income that was different than usual. On the weekend it was not really bad because people were still coming, but on the weekdays, you can see the difference". It can be interpreted that on weekdays, the income was declining because no one came, but on the weekend, people came so the income was higher. Income differences also occurred during the lockdown because people had to stay at home. They only go to restaurants to meet colleagues, friends or just want to eat at the restaurant.

Regarding the government regulation, $\mathrm{KH}$ said: "Yes, in the beginning of the pandemic we couldn't open, the restaurant was closed... And it closed for two months, because the restaurant would be fined if someone dined in the restaurant. So, you must eat at home, or in the garden that is very open". Thus, it can be concluded that government regulations related to lockdown in the form of the closures of restaurants in a certain period of time, no dine-in policy, and if the restaurant remained open it would be fined. People were only allowed to eat in open areas such as fields or parks.

The provision of assistance from the government was also carried out for restaurants in Germany, but less than optimal communication from the government causes unevenness of aid, as said by KH: "I heard from the news that there was help from the government, but as for the amount, I don't know. For us who rent a house or apartment, if we do not have money because of Coronavirus, and we do not have work and cannot pay the rent, we do not have to move out because the bill is paid by the government."

He also explained that the government will provide financial assistance if the restaurant's income is less than the previous year. The government is also rolling out operation hours, which allow customers to buy food or drinks before the closing time of the restaurants and have an impact on the use of online services for ordering food and beverages. Besides that, sales promotion and online delivery service were implemented to help the sustainability of restaurants in Germany, as $\mathrm{KH}$ said: "While we were doing the online service, some menus were discounted several times. I think it has quite a big impact, people buy 
them. Because it's cheaper". It can be concluded that online service and sales promotion on the menu can attract the customers to order the food even though the income generated it is not as big as the dine-in mode.

\section{Restaurant Sustainability in the Netherlands}

The Restaurant Sustainability in the Netherlands sub-theme was developed based on three categories: profit, government regulation, and the effect of the COVID-19 pandemic on restaurants. The sustainability of restaurants in the Netherlands was quite good, because they were not too affected by factors due to the COVID-19 pandemic. In terms of profit, ST from restaurant BP in the Netherland said: "We were quite lucky. Our revenue grew, but by how much I don't know, but it grew". Their situation got better due to the lockdown. ST added, "So the stricter the lockdown the busier we got, people couldn't go out to clubs because they were closed; they also could not go on vacations, and the restaurants were close. But they had to eat, so they just order take away from our restaurant"

ST also explained that in the Netherlands, the government played an active role in dealing with the pandemic and gave financial assistance to the restaurant owners, if the restaurant was unable to reopen or experienced a drastic decrease in revenue. The application of rules in restaurants was also regulated in local government regulations, ranging from distance control rules, on-site dining bans, to restrictions on operational time until $9 \mathrm{pm}$.

Regarding the effect of COVID-19 pandemic on restaurants, ST said, "Actually it's not a big deal but now we have to get new employees because during the pandemic there was a period that restaurants were closed, so many people quit. They are not so eager to come back because maybe they got other job, and we pay minimum wage". It can be concluded that many restaurant employees resigned after the closure at the time of the lockdown period, and they were less likely to come back to work at the restaurant due to minimum pay or because they had got another job.

\section{Discussion}

The dismissal process in Indonesia as described by the respondents was by using verbal communication, and no government or legal intervention occurred in the F\&B sector, especially in restaurants. The management and employees only had a discussion 'secara kekeluargaan' or had a face-to-face discussion, by sending a notification via mobile phone or text message beforehand.

Meanwhile, in the Netherlands, the dismissal process was based on employee resignations with verbal communication and clear reasons. According to Dutch respondents, there was no such procedural process using legal tools since they considered that their business or restaurant was only a small business, and if it had to go through the legal process, it would be very complex. In the process of dismissal, the restaurant management gave a little money to the employees who were laid off.

In Germany, the dismissal process was the same. Direct verbal communication was often applied between restaurant management and employees. The revocation of the status of employees who wished to resign was only done by notifying and submitting directly to the management party for reasonable reasons.

Regarding restaurant sustainability, restaurants in Indonesia experienced a sharp profit decrease compared with the profit they earned before the pandemic. Therefore, many restaurants could not survive during the pandemic and lockdown. The restaurants that still survived had to reduce their number of employees.

For the restaurants sustainability in Germany, there was a period that the restaurants had to be closed because of the enactment of a lockdown policy from the German government. However, they were able to survive and continue their restaurant business during the pandemic to date. The process of dismissing employees that occurred slightly affected restaurant sustainability because employees who resigned were burdened with double shifts that caused overwork, besides the wage factors. The regulations implemented by the government were also considered to be very influential on restaurant operations. The permit for dining in open spaces also give one-sided leeway to restaurants that had outdoor dine-in spaces such as balconies and on the roadside, so many people tended to come to restaurants that had outdoor facilities.

As for the Dutch restaurants, it was quite astonishing that the pandemic and lockdown had a positive impact for the restaurants so that the sustainability of the restaurant was maintained during the pandemic. On the employee management side, since several employees resigned during the pandemic when the restaurant was closed down, the management had to recruit new employees to replace them. However, people were not really interested to work in a restaurant because beside the low salary, they were still afraid of the virus and tried to prevent contact with others in an in-door area. 


\section{Conclusion and Implications}

This research aimed to discover the basis and process to terminates employee in the restaurant industry and business sustainability in Indonesia, Germany, and the Netherlands.

It was found that factors that affected the dismissal and resignation of employees tended to be based on employee enforcement factors, namely circumstances that were not expected and the resignations from employees were due to factors stemming from the COVID-19 pandemic. The process of employee dismissal that was caused by low performance was found to have no effect on restaurant sustainability. Restaurant sustainability was influenced more by profit, government regulations, and the pandemic effects of COVID-19. As mentioned above, the restaurants in Indonesia were not too successful in maintaining their sustainability, and that became one of the factors of the restaurant employees losing their jobs. In Germany, the employee factor determined the continuation of the restaurant because employees were overworked due to undergoing dual roles during the COVID-19 pandemic and the wages were considered low, so several employees resigned. Meanwhile, the restaurant in the Netherlands could maintain its sustainability, since people retained high interest in buying food during the pandemic. The employee's resignation process was also not very related to the pandemic because the employee had other activities and it was maybe only a wage factor that motivated them to quit.

The limitations that occurred during the research include limited mobility to reach the interviewees during the pandemic, the unclear situation during the COVID-19 pandemic that impacted the interviewees to reschedule the interview, and the access to the restaurants was quite limited because most of them were only providing several employees and managements to be interviewed.

For future research it is recommended to expand to several cities/regions in several countries and by involving more people including top management, staff, and other employees to get more varied data.

For the managerial implications: The results of this study may be useful to giving an insight into businesses in the field of $\mathrm{F} \& \mathrm{~B}$, especially restaurants during the COVID-19 pandemic, and to give consideration to the factors that will be faced in a crisis such as business closure to dismissal or resignation of employees.

\section{Acknowledgment}

This research is funded by: Directorate of Research and Community Service; Directorate General of Research and Development Strengthening; Ministry of Research and Technology / National Research and Innovation Agency; In accordance with the Research Contract for Fiscal Year 2021 Number: 163/SP2H/LT/DRPM/2021 March 18, 2021

\section{References}

Belluz, J. (2020). The 4 simple reasons Germany is managing COVID-19 better than its neighbors. Austria: vox.com. Retrieved from: https://www.vox.com/21495327/COVID-19-germany-coronaviruscases-deaths

Braun, V., \& Clarke, V. (2006). Using thematic analysis in psychology. Qualitative

Research in Psychology. 3(2). 77-101. https://doi.org/10.1191/1478088706qp063oa

Business Insider. (2020, April 13). Countries that are on Lockdown Because of Coronavirus. Retrieved from Business Insider: www.businessinsider.com/countries-on-lockdown-coronavirus-italy-2020-3

Creswell, J. W. (2009). Research design: Qualitative, quantitative, and mixed method

approaches (3rd edition). Sage Publications.

Federal Statistics Germany. (2021). Germany Unemployment Rate. Retrieved from Federal Statistical office. Retrieved from: https://tradingeconomics.com/germany/unemployment-rate

Food Insight. (2020). Consumer Survey: COVID-19's Impact on Food Purchasing, Eating Behaviors and Perceptions of Food Safety. INTERNATIONAL FOOD INFORMATION COUNCIL . https://foodinsight.org/consumer-surveys-COVID-19s-impact/

Future Learn. (2021, March 27). What is lockdown and what does it mean for you? Retrieved from Future Learn: https://www.futurelearn.com/info/blog/what-is-lockdown

Holigan, A. (2020, April 5). Coronavirus: Why Dutch lockdown may be a high-risk strategy. Retrieved from BBC: https://www.bbc.com/news/world-europe-52135814

Hough, B. (2003). Theories of termination of the contract of employment. Journal of Contract Law, 19, 134-154. Retrieved from: https://researchportal.port.ac.uk/portal/en/publications/theories-oftermination-of-the-contract-of-employment(6ac86a9c-f1 f8-41a2-9024-d525a1a18cc0)/export.html

IMF (2020, June 15). Kurzarbeit: Germany's Short-Time Work Benefit. Retrieved from IMF: https://www.imf.org/en/News/Articles/2020/06/11/na061120-kurzarbeit-germanys-short-timework-benefit 
Inc. (2020). Employee Termination. Retrieved from Samantha, G. (2020). Employee termination types. Chron. Retrieved from https://www.inc.com/encyclopedia/employee-termination.html

Indonesia Investment. (2021). Pengangguran di Indonesia. Retrieved from Indonesia Investment: https://www.indonesia-investments.com/id/keuangan/angka-ekonomimakro/pengangguran/item 255

Insight Talenta. (2020). Pengertian F\&B Service Modern serta Jenis-Jenis Trennya! Retrieved from Insight Talenta: https://www.talenta.co/blog/insight-talenta/pengertian-fb-service-modern-serta-jenisjenis-trennya/

Insight Talenta. (2020). PHK Karyawan : Pengertian, Jenis, Contoh Surat dan Perhitungan Pesangon. Retrieved from https://www.talenta.co/blog/insight-talenta/phk-karyawan-pengertian-jenis-contohsurat-dan-perhitungan-pesangon/

Jain, S. P. (2020). Effect of COVID - 19 on Restaurant Industry-how to cope with changing Demand. SSRN, 1. http://dx.doi.org/10.2139/ssrn.3577764

Joseph, A. (2021, April 19). Explained: What is the difference between curfew and lockdown? Retrieved from OneIndia: https://www.oneindia.com/india/explained-what-is-the-difference-betweencurfew-and-lockdown-3246762.html

Kiger, M. E., \& Varpio, L. (2020). Thematic analysis of qualitative data: AMEE Guide

No. 131. Medical Teacher, 42(8), 846-854. https://doi.org/10.1080/0142159X.2020.1755030

Lock, S. (2021). Daily Impact of COVID-19 on Restaurant Dining in Germany 2020. Retrieved from Statista: https://www.statista.com/statistics/1105090/coronavirus-restaurant-visitation-impactgerman/

Meier, L. (2019, November 11). A Guide On EmployeeTermination in germany. Retrieved from Universal Hires: https://universalhires.com/magazine/employee-termination-germany/

Muhammad, A. (2020). Langkah Pemerintah Atasi Wabah Corona Dinilai Lamban. Jakarta: Liputan 6. Retrieved from: https://www.liputan6.com/news/read/4208285/langkah-pemerintah-atasi-wabahcorona-dinilai-lamban

Netherlands Enterprise Agency. (2021, February 23). Dismissal procedures and protections. Retrieved from Business.Gov.nl: https://business.gov.nl/regulation/dismissal-procedures/

Plümper, T., \& Neumayer, E. (2020). Lockdown policies and the dynamics of the first wave of the SarsCoV-2 pandemic in Europe. Journal of European Public Policy, 1-21. https://doi.org/10.1080/13501763.2020.1847170

Prawithra, T., \& Sri, W. (2020). Company Policy on Termination of Employment at pandemic COVID-19 From a Fair and Justice Perspective. 2nd International Conference on Law, Governance and Social Justice (ICOLGAS 2020), 744. https://doi.org/10.2991/assehr.k.201209.359

Roy, F. (2020, June 12). Update Data Terbaru: Ada 3 Juta Orang Kena PHK di Indonesia. Retrieved from CNBC: https://www.cnbcindonesia.com/news/20200612180328-4-165046/update-data-terbaruada-3-juta-orang-kena-phk-di-indonesia

Netherlands Enterprise Agency. (2021, February 23). Dismissal procedures and protections. Retrieved from Business.Gov.nl: https://business.gov.nl/regulation/dismissal-procedures/

Plümper, T., \& Neumayer, E. (2020). Lockdown policies and the dynamics of the first wave of the SarsCoV-2 pandemic in Europe. Journal of European Public Policy, 1-21. https://doi.org/10.1080/13501763.2020.1847170

Prawithra, T., \& Sri, W. (2020). Company Policy on Termination of Employment at pandemic COVID-19 From a Fair and Justice Perspective. 2nd International Conference on Law, Governance and Social Justice (ICOLGAS 2020), 744. https://doi.org/10.2991/assehr.k.201209.359

Roy, F. (2020, June 12). Update Data Terbaru: Ada 3 Juta Orang Kena PHK di Indonesia. Retrieved from CNBC: https://www.cnbcindonesia.com/news/20200612180328-4-165046/update-data-terbaruada-3-juta-orang-kena-phk-di-indonesia

Seveno, V. (2020, August 20). Unemployment in the Netherlands continues to rise. Retrieved from iamexpat: $\quad$ https://www.iamexpat.nl/career/employment-news/unemployment-netherlandscontinues-rise

Statista. (2021). Annual average unemployment rate in Germany from 2005-2021. Retrieved from Statista: https://www.statista.com/statistics/227005/unemployment-rate-in-germany/

Statista. (2021). Netherlands: Unemployment rate from 1999 to 2020. Retrieved from Statista: https://www.statista.com/statistics/263703/unemployment-rate-in-the-netherlands/

Stewart, C. (2021, March 11). Number of new coronavirus (COVID-19) cases in Europe 2021. Retrieved from Statista: https://www.statista.com/statistics/1102209/coronavirus-cases-development-europe/ 
The Jakarta Post. (2020). West Java sees mass layoffs due to COVID-19. Jakarta: The Jakarta Post. Retrieved from https://www.thejakartapost.com/news/2020/11/03/west-java-sees-mass-layoffsdue-to-COVID-19.html

Thoha, N. \& Avandana, I. M. N. W. (2020). Project Managers' Leadership Styles and Their Effects on Project Management Performance. Pertanika Journal Social Science \& Humanities, 28(2), 803-816. Retrieved from https://binusianorgmy.sharepoint.com/personal/nurianna_binus_edu/Documents/Attachments/JSSH\%20Vol.\%2028\% 20(2)\%20Jun.\%202020\%20(View\%20Full\%20Journal)\%201.pdf

Ward, S. (2020). What Are SMEs? Retrieved from The Balance Small Business: https://www.thebalancesmb.com/sme-small-to-medium-enterprise-definition-2947962

WHO. (2020). WHO. Retrieved from Severe Acure Respiratory Syndrome: https://www.who.int/healthtopics/severe-acute-respiratory-syndrome\#tab=tab_1 